\title{
Effect of the nature and location of copper species on catalytic nitric oxide selective catalytic reduction performance of the copper/SSZ-13 zeolite
}

\section{Citation for published version (APA):}

Guo, Q., Fan, F., Ligthart, D. A. J. M., Li, G., Feng, Z., Hensen, E. J. M., \& Li, C. (2014). Effect of the nature and location of copper species on catalytic nitric oxide selective catalytic reduction performance of the copper/SSZ13 zeolite. ChemCatChem, 6(2), 634-639. https://doi.org/10.1002/cctc.201300775

DOI:

10.1002/cctc. 201300775

Document status and date:

Published: 01/01/2014

\section{Document Version:}

Publisher's PDF, also known as Version of Record (includes final page, issue and volume numbers)

\section{Please check the document version of this publication:}

- A submitted manuscript is the version of the article upon submission and before peer-review. There can be important differences between the submitted version and the official published version of record. People interested in the research are advised to contact the author for the final version of the publication, or visit the DOI to the publisher's website.

- The final author version and the galley proof are versions of the publication after peer review.

- The final published version features the final layout of the paper including the volume, issue and page numbers.

Link to publication

\footnotetext{
General rights

- You may freely distribute the URL identifying the publication in the public portal. follow below link for the End User Agreement:

www.tue.nl/taverne

\section{Take down policy}

If you believe that this document breaches copyright please contact us at:

openaccess@tue.nl

providing details and we will investigate your claim.
}

Copyright and moral rights for the publications made accessible in the public portal are retained by the authors and/or other copyright owners and it is a condition of accessing publications that users recognise and abide by the legal requirements associated with these rights.

- Users may download and print one copy of any publication from the public portal for the purpose of private study or research.

- You may not further distribute the material or use it for any profit-making activity or commercial gain

If the publication is distributed under the terms of Article $25 \mathrm{fa}$ of the Dutch Copyright Act, indicated by the "Taverne" license above, please 


\title{
Effect of the Nature and Location of Copper Species on the Catalytic Nitric Oxide Selective Catalytic Reduction Performance of the Copper/SSZ-13 Zeolite
}

\author{
Qiang Guo, ${ }^{[a, b]}$ Fengtao Fan, ${ }^{[a]}$ D. A. J. Michel Ligthart, ${ }^{[b]}$ Guanna Li, ${ }^{[a, b]}$ Zhaochi Feng, ${ }^{[a]}$ \\ Emiel J. M. Hensen, ${ }^{*[b]}$ and Can $\mathrm{Li}^{*[a]}$
}

\begin{abstract}
The nature and location of copper in Cu/SSZ-13 zeolites synthesized by using a one-pot hydrothermal approach with $\mathrm{Cu}$ tetraethylenepentamine as a template and by the ion exchange of SSZ-13 were investigated by applying $\mathrm{H}_{2}$-temperature-programmed reduction, FTIR, EPR, and in situ Raman spectroscopic techniques. The one-pot synthesized Cu/SSZ-13 zeolite contains predominantly isolated copper ions in the large cages, whereas copper species in the ion-exchanged Cu/SSZ13 zeolite occupy sites in the large cages of the chabazite (CHA) structure and the six-membered rings of the CHA structure. If the one-pot synthesized $\mathrm{Cu} / \mathrm{SSZ}-13$ zeolite is exchanged with the $\mathrm{NH}_{4} \mathrm{NO}_{3}$ solution in addition to the removal of a part
\end{abstract}

of copper ions, the remaining copper ions in the $\mathrm{CHA}$ structure relocated from the large cages to the six-membered rings. Isolated copper dominated in all $\mathrm{Cu} / \mathrm{SSZ}-13$ zeolites. The in situ Raman spectra demonstrated that $\mathrm{Cu}-\mathrm{O}-\mathrm{Cu}$ dimers form at higher copper content. The bis- $\mu$-oxo dicopper(III) complex is observed only in the ion-exchanged sample upon dehydration. The higher NO selective catalytic reduction activity of the onepot synthesized sample in a wide temperature range appears to be due to the predominance of isolated $\mathrm{Cu}^{2+}$ sites in the large cages, and their higher reactivity is possibly owing to the lower stability of $\mathrm{Cu}^{2+}$ at these sites.

\section{Introduction}

The selective catalytic reduction (SCR) of nitrogen oxides $\left(\mathrm{NO}_{x}\right)$ with ammonia $\left(\mathrm{NH}_{3}-\mathrm{SCR}\right)$ is an efficient way for $\mathrm{NO}_{x}$ abatement. ${ }^{[1-3]}$ Copper-containing zeolites are one of the most active catalyst systems for the related reactions. ${ }^{[3-8]}$ The most extensive studies have been performed on Cu/ZSM-5 and $\mathrm{Cu} /$ BEA zeolites. Cu/BEA demonstrates excellent activity with better hydrothermal stability than does Cu/ZSM-5. ${ }^{[7,9-11]}$ The ion-exchanged copper-containing SSZ-13 zeolite, based on the small-pore chabazite (CHA) zeolite topology, recently demonstrated higher activity and selectivity to $\mathrm{N}_{2}$ over a wide temperature range and better hydrothermal stability than did $\mathrm{Cu}$ / ZSM-5 and Cu/BEA zeolites. ${ }^{[12-17]}$

Typically, the catalytic SCR performance of the copper-containing zeolite greatly depends on the location and nature of

[a] Q. Guo, Dr. F. Fan, Dr. G. Li, Prof. Dr. Z. Feng, Prof. Dr. C. Li

State Key Laboratory of Catalysis

Dalian Institute of Chemical Physics

Chinese Academy of Sciences

457 Zhongshan Road, Dalian 116023 (P.R. China)

Fax: $(+86)$ 411-8469-4447

E-mail:canli@dicp.ac.cn

[b] Q. Guo, Dr. D. A. J. M. Ligthart, Dr. G. Li, Prof. Dr. E. J. M. Hensen

Laboratory of Inorganic Materials Chemistry

Schuit Institute of Catalysis

Eindhoven University of Technology

P.O. Box 513, 5600 MB Eindhoven (The Netherlands)

Fax:/Homepage: www.catalysis.nl/imc

E-mail:e.j.m.hensen@tue.nl

Supporting information for this article is available on the WWW under http://dx.doi.org/10.1002/cctc.201300775. copper species. The existence of various types of copper species in the zeolite has been proposed: $\mathrm{Cu}^{2+}$ and $\mathrm{Cu}^{+}$monomers, $[\mathrm{Cu}-\mathrm{O}-\mathrm{Cu}]^{2+}$ dimers, and $\mathrm{CuO}_{x}$ clusters. ${ }^{[17-19]}$ Isolated $\mathrm{Cu}^{2+}$ species are usually postulated as the active sites in the SCR reaction. ${ }^{[20-22]}$ The preparation method strongly affects the nature and speciation of the copper phase. In general, monomeric copper ions located at the cation-exchange sites dominate in ion-exchanged samples, with the fraction of $[\mathrm{Cu}-\mathrm{O}-$ $\mathrm{Cu}]^{2+}$ dimers typically becoming more important with increasing $\mathrm{Cu}$ content. ${ }^{[18]}$ In contrast, precipitation usually results in the formation of a separate $\mathrm{CuO}$ phase located at the external zeolite surface. ${ }^{[17-19]}$ Lobo et al. suggested that $\mathrm{Cu}^{2+}$ ions are located in the six-membered rings of the $\mathrm{CHA}$ structure. ${ }^{[23]}$ Combining extended $\mathrm{X}$-ray absorption fine structure and in situ UV/Vis spectroscopy, Beale et al. proposed that isolated mononuclear $\mathrm{Cu}^{2+}$ species slightly shifted toward the edge of the six-membered rings. ${ }^{[20]}$ Kwak et al. reported that the location of copper species depends on the copper content if the ion-exchange method is used to prepare the $\mathrm{Cu} / \mathrm{SSZ}-13$ zeolite. ${ }^{[15]}$ Copper ions prefer to occupy sites in the six-membered rings over those in the large cages of the $\mathrm{CHA}$ structure. ${ }^{[15]} \mathrm{A}$ copper complex was used recently in the synthesis of Cu/SSZ13 , which has the dual function of acting as the template for SSZ-13 formation as well as loading copper at specific locations in the zeolite micropores. The method using the $\mathrm{Cu}^{2+}$ -tetraethylenepentamine (Cu-TEPA) complex for the one-pot synthesis of the $\mathrm{Cu} / \mathrm{SSZ}-13$ zeolite was first reported by Xiao et al. ${ }^{[24]}$ The resulting Cu/SSZ-13 materials demonstrate high activity in the SCR of NO over a wide temperature range. ${ }^{[24,25]}$ 
Corma et al. also described the one-pot synthesis of the $\mathrm{Cu}$ / SSZ-13 zeolite with a combination of templates (CU-TEPA and $\mathrm{N}, \mathrm{N}, \mathrm{N}$-trimethyl-1-adamantammonium hydroxide). The material used by Corma et al. was highly active and stable for the SCR of $\mathrm{NO}_{x}$, even under severe reaction conditions. ${ }^{[26,27]}$ The same group has also described the one-pot synthesis of the $\mathrm{Cu}$ / SAPO-34 zeolite with a combination of inexpensive templates (Cu-TEPA and diethylamine). ${ }^{[2]}$ One expects that $\mathrm{Cu} / \mathrm{SSZ}-13$ prepared by using this method will have more uniformly speciated copper species than comparatively less active zeolites prepared by using conventional methods. So far, however, the location and nature of copper species in one-pot synthesized and ion-exchanged $\mathrm{Cu} / \mathrm{SSZ}-13$ zeolites have not been investigated in detail.

Herein, Cu/SSZ-13 zeolites were prepared by using one-pot and ion-exchange methods and characterized by applying $\mathrm{H}_{2}-$ temperature-programmed reduction $\left(\mathrm{H}_{2}-\mathrm{TPR}\right), \mathrm{IR}$, EPR, and Raman spectroscopy techniques to study the location and nature of copper species. Our study demonstrates that 1) the copper ions in the one-pot synthesized sample are more uniformly speciated as highly dispersed isolated ions in the large cages of the SSZ-13 micropores. In contrast, copper ions in the ion-exchanged sample occupy sites in the small six-membered rings and the large cages of the $\mathrm{CHA}$ structure; 2 ) if the onepot synthesized sample is treated with $\mathrm{NH}_{4} \mathrm{NO}_{3}$, a part of copper ions are exchanged by ammonium ions and the remaining copper ions migrate from the larges cages to the more stable location in the six-membered rings; and 3) monomeric copper ions dominate in all samples and more dimeric $\mathrm{Cu}-\mathrm{O}-\mathrm{Cu}$ species are present in samples with higher copper content. Meanwhile, the bis- $\mu$-oxo dicopper(III) complex is observed only in the ion-exchanged Cu/SSZ-13 zeolite. The high catalytic activity in the SCR of NO appears to be related to isolated copper ions located in the large cages of the SSZ-13 structure.

\section{Results and Discussion}

The elemental composition of Cu/SSZ-13 zeolites as determined by inductively coupled plasma optical emission spectrometry (ICP-OES) analysis is listed in Table 1. The copper loading did not result in a change in the Si/Al content of the parent SSZ-13 zeolite. The one-pot synthesized sample had a similar $\mathrm{Si} / \mathrm{Al}$ ratio and $\mathrm{Cu} / \mathrm{Al}$ ratio as did the ion-exchanged zeolite. The subsequent treatment with $\mathrm{NH}_{4} \mathrm{NO}_{3}$ solutions did not affect the Si/Al ratio but led to a gradual decrease in the

\begin{tabular}{|llcr|}
\hline $\begin{array}{l}\text { Table 1. Elemental composition of } \mathrm{Cu} / \mathrm{SSZ}-13 \\
\text { from ICP-OES analysis. }\end{array}$ & zeolites as determined \\
Sample & $\mathrm{NH}_{4} \mathrm{NO}_{3}$ concentration [M] & Si/Al & $\mathrm{Cu} / \mathrm{Al}$ \\
\hline $\mathrm{IE}-0.36$ & - & 4.3 & 0.357 \\
OP-0.37 & - & 4.3 & 0.365 \\
OP-0.26 & 0.01 & 4.3 & 0.259 \\
OP-0.09 & 0.025 & 4.3 & 0.090 \\
OP-0.04 & 0.05 & 4.3 & 0.036 \\
\hline
\end{tabular}

$\mathrm{Cu} / \mathrm{Al}$ ratio with an increase in $\mathrm{NH}_{4} \mathrm{NO}_{3}$ concentration. The XRD patterns demonstrate that $\mathrm{Cu} / \mathrm{SSZ}-13$ zeolites synthesized by ion exchange (IE-0.36: ion-exchanged sample with $\mathrm{Cu} / \mathrm{Al}=$ 0.36 ) and by one-pot synthesis (OP-0.37: one-pot synthesized sample with $\mathrm{Cu} / \mathrm{Al}=0.37$ ) are highly crystalline and demonstrate the CHA structure (Figure S1, traces a and b). Notably, $\mathrm{CuO}$ cannot be observed in the XRD patterns of these samples, which is an indication of the high dispersion of the copper phase.

The $\mathrm{H}_{2}$-TPR curves used to investigate the reducibility of intrazeolitic copper species in the $\mathrm{Cu} / \mathrm{SSZ}-13$ zeolite are shown in Figure 1. For the ion-exchanged sample (IE-0.36), a strong

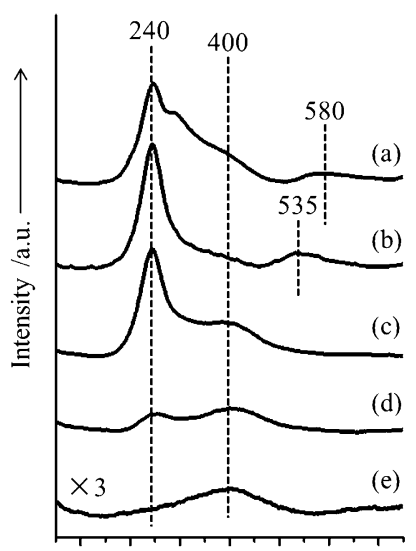

100200300400500600700 Temperature/ ${ }^{\circ} \mathrm{C} \longrightarrow$

Figure 1. $\mathrm{H}_{2}$-TPR profiles of all $\mathrm{Cu} / \mathrm{SSZ}-13$ zeolites: a) IE-0.36, b) OP-0.37, c) OP-0.26, d) OP-0.09, and e) OP-0.04.

reduction feature at $240{ }^{\circ} \mathrm{C}$ with a shoulder at $400^{\circ} \mathrm{C}$ is observed (Figure $1 \mathrm{a}$ ), which was attributed to the reduction of isolated $\mathrm{Cu}^{2+}$ to $\mathrm{Cu}^{+}$at different cation positions in the zeolite structure. ${ }^{[15]}$ The lower reduction feature arises from the relatively easy reduction of $\mathrm{Cu}^{2+}$ located in the large cages of the CHA structure, whereas the higher temperature feature arises from the reduction of $\mathrm{Cu}^{2+}$ in the six-membered rings. The one-pot synthesized sample (OP-0.37) demonstrates only a single $\mathrm{H}_{2}$-TPR reduction feature at $240^{\circ} \mathrm{C}$ (Figure $1 \mathrm{~b}$ ). Thus, $\mathrm{Cu}^{2+}$ ions are predominantly located in the large cages of the CHA structure in this sample.

To elucidate the origin of this difference between the two $\mathrm{Cu} / \mathrm{SSZ}-13$ zeolites, the OP-0.37 sample was ion exchanged with a series of $\mathrm{NH}_{4} \mathrm{NO}_{3}$ solutions of increasing concentration. The reducibility of copper species in the resulting zeolites was studied by using $\mathrm{H}_{2}$-TPR. With the increase in $\mathrm{NH}_{4} \mathrm{NO}_{3}$ concentration, the copper content in $\mathrm{Cu} / \mathrm{SSZ}-13$ zeolites decreased gradually (Table 1). Meanwhile, the reduction feature at $240^{\circ} \mathrm{C}$ decreased concomitant with the appearance of a new feature at $400{ }^{\circ} \mathrm{C}$ (Figure $1 \mathrm{c}$ and $\mathrm{d}$ ). This result indicates that some of the remaining $\mathrm{Cu}^{2+}$ ions relocate from positions in the large cages of the CHA structure to cation-exchange positions in the six-membered rings during the ion-exchange process with the $\mathrm{NH}_{4} \mathrm{NO}_{3}$ solution. With use of a more concentrated $\mathrm{NH}_{4} \mathrm{NO}_{3}$ so- 
lution, only the reduction feature at $400^{\circ} \mathrm{C}$ was observed (Figure $1 \mathrm{e})$. This tendency is consistent with the known higher stability of $\mathrm{Cu}^{2+}$ in the small rings. ${ }^{[15]}$ During one-pot synthesis, $\mathrm{Cu}^{2+}$ ions are chelated by amine complexes and are thus too large to be present in the six-membered rings. ${ }^{[2,25]}$ However, during ion exchange, $\mathrm{Cu}^{2+}$ ions prefer to locate in their more stable positions.

In addition to these features in the $\mathrm{H}_{2}$-TPR profiles, there are reduction peaks located at 580 and $535^{\circ} \mathrm{C}$ for IE-0.36 and OP0.37 samples, respectively. These relatively higher temperature reduction peaks are attributed to the reduction of copper dimers from $\mathrm{Cu}^{+}$to $\mathrm{Cu}^{0}$ and to the reduction from $\mathrm{Cu}^{+}$monomers to $\mathrm{Cu}^{0}$, which occurs only at high temperatures with the collapse of the CHA structure. ${ }^{[13]}$ Thus, it is reasonable to propose the formation of copper dimers in these samples.

The FTIR spectroscopy of adsorbed CO was performed to study the chemical state of copper sites and their environment in the zeolite. ${ }^{[15,16]}$ The pretreatment process results in the autoreduction of $\mathrm{Cu}^{2+}$ ions in the zeolite. The IR spectra of $\mathrm{CO}$ adsorbed on the $\mathrm{Cu} / \mathrm{SSZ}-13$ zeolite as a function of CO coverage are shown in Figure 2. The IR spectrum of the IE-0.36 sample (Figure $2 \mathrm{a}$ ) demonstrates two distinct absorption bands centered at 2145 and $2155 \mathrm{~cm}^{-1}$ and labeled as LF (lowfrequency) and HF (high-frequency) bands, respectively. These two bands relate to $\mathrm{CO}$ coordinated to $\mathrm{Cu}^{+}$sites in the sixmembered rings (LF) and large cages of the CHA structure (HF). ${ }^{[16]}$ With the increase in CO coverage, the sites associated with the LF band become saturated with $\mathrm{CO}$ whereas the sites in the large cages of the CHA structure are still getting populated. Meanwhile, a new band located at $2180 \mathrm{~cm}^{-1}$ appeared and its intensity became stronger with the increase in CO coverage. This band was assigned to dicarbonyl species bounded to $\mathrm{Cu}^{+} \cdot{ }^{[16]}$ The IR spectrum of the OP-0.37 sample demonstrates only one absorption band at $2155 \mathrm{~cm}^{-1}$ (Figure $2 \mathrm{~b}$ ), irrespective of the CO coverage. Consistent with the TPR results, the FTIR results demonstrate that all copper ions are located in the large cages of the CHA structure in the one-pot synthesized Cu/SSZ-13 zeolite. As expected, if OP-0.37 was ion exchanged with $\mathrm{NH}_{4} \mathrm{NO}_{3}$, the IR spectra of these samples demonstrate two distinct absorption bands centered at 2145 and $2155 \mathrm{~cm}^{-1}$ (Figure $2 \mathrm{c}-\mathrm{e}$ ). This result indicates that the remaining $\mathrm{Cu}^{2+}$ ions in the $\mathrm{CHA}$ structure relocated during ion exchange.

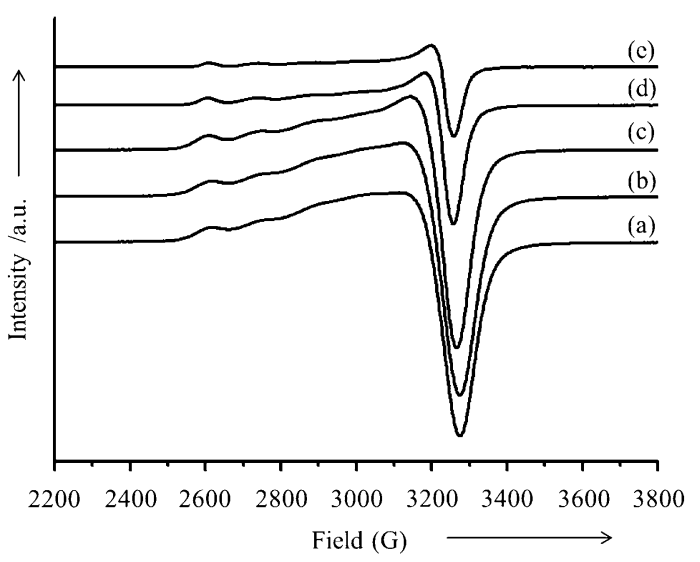

Figure 3. EPR spectra of CU/SSZ-13 zeolites measured at $100 \mathrm{~K}$ : a) IE-0.36, b) OP-0.37, c) OP-0.26, d) OP-0.09, and e) OP-0.04.

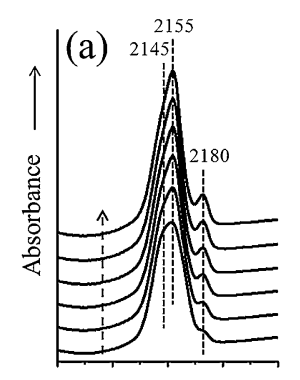

$20502100 \quad 2150 \quad 2200 \quad 2250$ Wavenumbers $/ \mathrm{cm}^{-1} \longrightarrow$

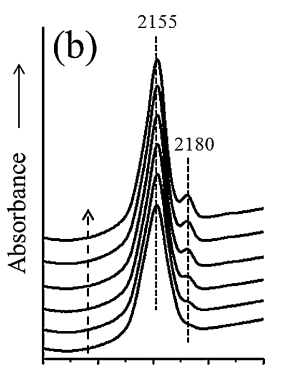

$\begin{array}{lllll}2050 & 2100 & 2150 & 2200 & 2250\end{array}$ Wavenumbers $/ \mathrm{cm}^{-1} \longrightarrow$

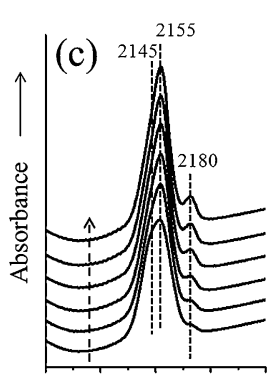

$\begin{array}{lllll}2050 & 2100 & 2150 & 2200 & 2250\end{array}$ Wavenumbers $/ \mathrm{cm}^{-1} \longrightarrow$

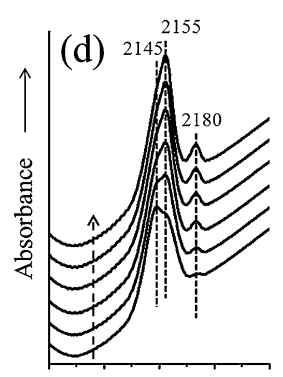

$\begin{array}{lllll}2050 & 2100 & 2150 & 2200 \quad 2250\end{array}$ Wavenumbers $/ \mathrm{cm}^{-1} \longrightarrow$

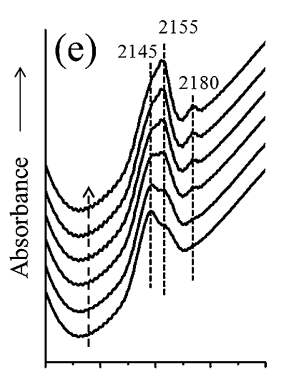

$\begin{array}{lllll}2050 & 2100 & 2150 & 2200 & 2250\end{array}$ Wavenumbers $/ \mathrm{cm}^{-1} \longrightarrow$
Figure 2. FTIR spectra of CO adsorbed on Cu/SSZ-13 zeolites: a) IE-0.36, b) OP-0.37, c) OP0.26 , d) OP-0.09, and e) OP-0.04. The dotted arrow indicates an increase in the gas phase equilibrium pressure of $\mathrm{CO}$.
The EPR spectra of Cu-SSZ-13 zeolites were recorded at $100 \mathrm{~K}$, in which the characteristic copper hyperfine structure can be resolved. The characteristic structure of $\mathrm{Cu}^{2+}$ complexes is shown in Figure 3, which results from hyperfine coupling between the $3 d$ unpaired electron and the copper $(I=3 / 2)$ nuclear spin. ${ }^{[25]}$ The spectral features agree well with the isolated octahedral copper complexes observed in zeolites, in which the surrounding ligands are water or hydroxyl groups. ${ }^{[16,29,30]}$ This result implies that all the Cu-SSZ-13 samples contain predominantly isolated copper species, which is in accordance with the work of Lamberti et al. ${ }^{[31]}$ On the basis of the results of extended X-ray absorption fine structure and UV/Vis spectroscopy, Beale et al. proposed that isolated $\mathrm{Cu}^{2+}$ is the active site for the $\mathrm{NH}_{3}-\mathrm{SCR}$ reaction. ${ }^{[20-22]}$ The EPR spectra of OP-0.37 and IE-0.36 samples demonstrate the same features (Figure $3 a$ and $b$ ). If the OP0.37 sample is ion exchanged with the $\mathrm{NH}_{4} \mathrm{NO}_{3}$ solution, the copper content decreases (Table 1). The EPR signal intensity becomes stronger with the increase in copper content (Figure 3). Meanwhile, the peak width increases, which stems from the dipole-dipole interactions between $\mathrm{Cu}^{2+}$ ions. This finding demonstrates that the distance between $\mathrm{Cu}^{2+}$ ions becomes 
shorter as the copper loading increases, which in turn indicates that the formation of copper dimers is highly possible in the samples with high copper loadings.

Furthermore, the overall intensity of the EPR spectra decreased significantly if the samples were dehydrated before the measurement because $\mathrm{Cu}^{2+}$ species are autoreduced to $\mathrm{Cu}^{+}$species. This explanation was discarded earlier by Lamberti et al. ${ }^{[31]}$ These authors put forward, as the most reasonable explanation, that the loss of EPR intensity is due to a change in the coordination environment (water is removed, and the interaction of $\mathrm{Cu}^{2+}$ ions with the oxygen anions of the zeolite increase). We refer to the work of Lamberti et al for relevant explanations for the change in the EPR spectra.

The in situ Raman spectra were collected for high-temperature calcined Cu/SSZ-13 samples (Figure 4). All samples demonstrate the characteristic Raman band of the $\mathrm{CHA}$ structure at $475 \mathrm{~cm}^{-1}$. In addition, the Raman spectra of the IE-0.36 and

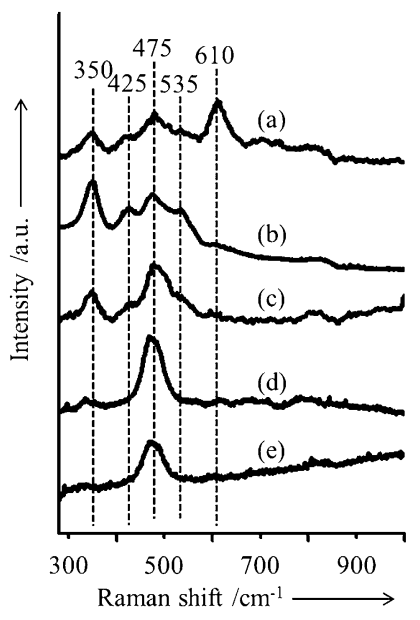

Figure 4. In situ Raman spectra of Cu/SSZ-13 zeolites: a) IE-0.36, b) OP-0.37, c) OP-0.26, d) OP-0.09, and e) OP-0.04.

OP-0.37 samples demonstrate an intense Raman band at $350 \mathrm{~cm}^{-1}$ and two weak bands at 425 and $535 \mathrm{~cm}^{-1}$ (Figure $4 \mathrm{a}$ and $b$ ). These bands relate to $\mathrm{Cu}-\mathrm{O}-\mathrm{Cu}$ vibrations, which generally fall in the $350-600 \mathrm{~cm}^{-1}$ region. ${ }^{[18]}$ Notably, the use of laser excitation at 325 and $266 \mathrm{~nm}$ did not give rise to these bands in the Raman spectra, which confirms that these vibrations are in resonance with the electronic transition. Schoonheydt et al. reported that the vibrational frequency of $\mathrm{Cu}-\mathrm{O}-$ $\mathrm{Cu}$ species is highly dependent on the $\mathrm{Cu}-\mathrm{O}-\mathrm{Cu}$ angle. In the Cu/ZSM-5 zeolite, this angle is approximately $140^{\circ} .^{[18]}$ We performed DFT calculations to correlate the Raman shift to the $\mathrm{Cu}-\mathrm{O}-\mathrm{Cu}$ angle for a model representing $\mathrm{Cu} / \mathrm{SSZ}-13$ zeolite (Figure S2). Our calculation suggests that the $\mathrm{Cu}-\mathrm{O}-\mathrm{Cu}$ symmetric stretching frequency at $361 \mathrm{~cm}^{-1}$ corresponds to a $\mathrm{Cu}-$ $\mathrm{O}-\mathrm{Cu}$ angle of $160^{\circ}$, which is in good agreement with the experimental data $\left(350 \mathrm{~cm}^{-1}\right.$; Figure $4 \mathrm{a}$ and b). The occurrence of $\mathrm{Cu}-\mathrm{O}-\mathrm{Cu}$ species for these samples is consistent with their high copper loadings. Compared with the OP-0.37 sample, the Raman band arising from $\mathrm{Cu}-\mathrm{O}-\mathrm{Cu}$ species greatly weakened in intensity $\left(I_{350} / I_{475}\right)$ with the decrease in the $\mathrm{Cu} / \mathrm{Al}$ ratio in the $\mathrm{Cu} / \mathrm{SSZ}-13$ zeolite to 0.26 (Figure $4 \mathrm{~b}$ and $\mathrm{c}$ ). The absence of a band at $350 \mathrm{~cm}^{-1}$ in the Raman spectra of OP-0.09 and OP0.04 samples confirms that these samples do not contain $\mathrm{Cu}-\mathrm{O}-\mathrm{Cu}$ species (Figure $4 \mathrm{~d}$ and e).

Interestingly, an additional Raman band at $610 \mathrm{~cm}^{-1}$ is observed exclusively in the spectrum of the IE- 0.36 sample (Figure $4 \mathrm{a}$ ). This copper-related Raman band has been assigned to a bis- $\mu$-oxo dicopper(III) complex. ${ }^{[32]}$ This assignment is supported by DFT calculations $\left(591 \mathrm{~cm}^{-1}\right.$; Figure S3). The $\mathrm{Cu}-\mathrm{O}-$ $\mathrm{Cu}$ angle of $110^{\circ}$ matches well with the predictions by the Schoonheydt group. ${ }^{[18]}$ This result confirms that the speciation of copper in the one-pot synthesized sample is more uniform than in the ion-exchanged sample.

The NO conversion over Cu/SSZ-13 zeolites is plotted in Figure 5 as a function of the reaction temperature in the temperature range $150-500^{\circ} \mathrm{C}$. Cu/SSZ-13 zeolites with low copper

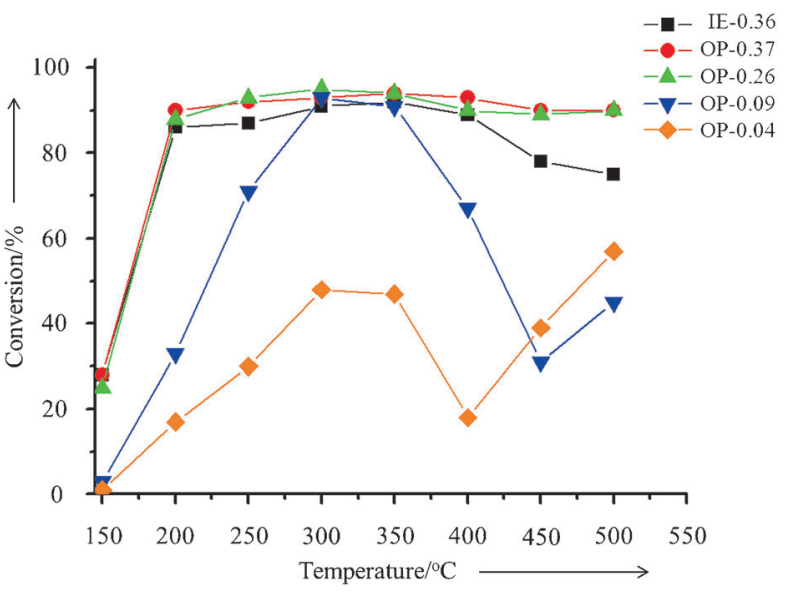

Figure 5. NO conversion profile of $\mathrm{Cu} / \mathrm{SSZ}-13$ at various temperatures in a gas mixture containing $1000 \mathrm{ppm}$ of $\mathrm{NO}, 1000 \mathrm{ppm}$ of $\mathrm{NH}_{3}$, and $5 \%$ of $\mathrm{O}_{2}$ with balance of $\mathrm{He}$.

content demonstrated low activities than did catalysts with high copper content, which is mainly due to the lower density of active sites of the lesser active materials. The OP-0.37 and OP-0.26 samples maintain their high conversion (>90\%) up to $500^{\circ} \mathrm{C}$, whereas the NO conversion of the IE- 0.36 sample decreased above $400^{\circ} \mathrm{C}$. This difference in performance at high temperature is consistent with the work of Xiao et al., who were the first to report the one-pot synthesis of the $\mathrm{Cu} / \mathrm{SSZ}-13$ zeolite. $^{[24,25]}$ The NO reduction activity was suppressed at high temperatures if the ion-exchanged $\mathrm{Cu} / \mathrm{SSZ}-13$ zeolite with high copper content was used for the SCR of $\mathrm{NO}_{x}{ }^{[14]}$ The copper loading in the OP-0.37 and IE-0.36 samples are the same (Table 1). Although the isolated copper ions dominate in both samples as demonstrated by the EPR spectra, the distribution of copper ions and their nature after dehydration are different, as confirmed from TPR, CO IR, and Raman spectroscopy. Copper species in the OP-0.37 sample are more uniform and mainly consist of isolated cations located in the large cages of the zeolite micropore space, whereas copper species in the IE- 
0.36 sample are present in the large cages as well as the sixmembered rings of the CHA structure. In addition, the dehydrated samples contain $\mathrm{Cu}-\mathrm{O}-\mathrm{Cu}$ dimers. Meanwhile, the bis$\mu$-oxo dicopper(III) complex is found only in the IE-0.36 sample. Thus, we conclude that the homogeneous speciation of copper in the form of isolated ions in the large cages of the one-pot synthesized $\mathrm{Cu} / \mathrm{SSZ}-13$ zeolite accounts for its high NO SCR activity in a wide temperature range. The higher activity of $\mathrm{Cu}^{2+}$ ions in the large cages could be related to their lower binding energy to the zeolite lattice compared with $\mathrm{Cu}^{2+}$ ions located in the smaller coordination environment of the six-membered rings.

\section{Conclusions}

$\mathrm{H}_{2}$-temperature-programmed reduction, $\mathrm{CO} I \mathrm{R}$, EPR, and Raman spectroscopy techniques were used to study the nature and location of copper species in $\mathrm{Cu} / \mathrm{SSZ}-13$ zeolites synthesized by using a one-pot hydrothermal approach with $\mathrm{Cu}$-tetraethylenepentamine as a template and by ion exchange of SSZ-13. The copper ions in the ion-exchanged sample occupy sites in the six-membered rings and the large cages of the chabazite structure, whereas they occupy only the latter sites in the one-pot synthesized sample. Dimeric $\mathrm{Cu}-$ $\mathrm{O}-\mathrm{Cu}$ species were observed in both samples after dehydration, and the bis- $\mu$-oxo dicopper(III) complex is present exclusively in the ion-exchanged sample. The higher activity in a wide temperature range of the one-pot synthesized sample appears to be due to the predominance of isolated $\mathrm{Cu}^{2+}$ sites in the large cages, and their higher reactivity is possibly owing to the lower stability of $\mathrm{Cu}^{2+}$ at these sites.

\section{Experimental Section}

\section{Catalyst preparation}

Cu/SSZ-13 was prepared by using a one-pot method according to the literature. ${ }^{[24,25]}$ Briefly, $\mathrm{NaAlO}_{2}(0.514 \mathrm{~g})$ and $\mathrm{NaOH}(0.38 \mathrm{~g})$ were dissolved in $\mathrm{H}_{2} \mathrm{O}$. Then, $\mathrm{CuSO}_{4} \cdot 5 \mathrm{H}_{2} \mathrm{O}(1.149 \mathrm{~g})$ was added to this solution, followed by the addition of TEPA $(1.07 \mathrm{~g})$; the mixture was stirred continuously for $1 \mathrm{~h}$. Silica sol (3.6 mL, $31.5 \mathrm{wt} \%)$ was added to the above gel under vigorous stirring. After stirring for $2 \mathrm{~h}$, the final gel was transferred to a Teflon-lined stainless steel autoclave and heated at $140^{\circ} \mathrm{C}$ for 6 days. The product was collected through filtration, washed with deionized $\mathrm{H}_{2} \mathrm{O}$, and dried at $110^{\circ} \mathrm{C}$ overnight. To remove the copper that did not coordinate with TEPA in the as-synthesized Cu/SSZ-13 zeolite, ion exchange with the $\mathrm{NH}_{4} \mathrm{NO}_{3}$ solution was performed before calcination: for this purpose, $\mathrm{Cu} / \mathrm{SSZ}-13(1 \mathrm{~g})$ was ion exchanged with the $\mathrm{NH}_{4} \mathrm{NO}_{3}$ solution $(100 \mathrm{~mL}, 1 \mathrm{M})$ at $80^{\circ} \mathrm{C}$ for $12 \mathrm{~h}$. After washing with deionized $\mathrm{H}_{2} \mathrm{O}$ and drying at $110^{\circ} \mathrm{C}$ overnight, the product obtained was calcined at $550^{\circ} \mathrm{C}$ for $8 \mathrm{~h}$ in static air. This sample was labeled OP0.37 , with the suffix indicating the $\mathrm{Cu} / \mathrm{Al}$ ratio. The copper content in the one-pot synthesized $\mathrm{Cu} / \mathrm{SSZ}-13$ zeolite was adjusted by ion exchange with solutions of increasing $\mathrm{NH}_{4} \mathrm{NO}_{3}$ concentration. In a typical exchange experiment, the calcined $\mathrm{Cu} / \mathrm{SSZ}-13$ zeolite $(1 \mathrm{~g})$ was ion exchanged with $\mathrm{NH}_{4} \mathrm{NO}_{3}(0.08 \mathrm{~g})$ in $\mathrm{H}_{2} \mathrm{O}(100 \mathrm{~mL})$ at $\mathrm{RT}$ for $5 \mathrm{~h}$. After washing with deionized $\mathrm{H}_{2} \mathrm{O}$ and drying at $110^{\circ} \mathrm{C}$ overnight, the product was calcined at $550^{\circ} \mathrm{C}$ for $4 \mathrm{~h}$ in static air. These samples were labeled $\mathrm{OP}-x$, with $x$ indicating the final $\mathrm{Cu} / \mathrm{Al}$ ratio.
For comparison, a Cu/SSZ-13 zeolite was obtained through ion exchange of $\mathrm{H}$-SSZ-13 with a $\mathrm{Cu}\left(\mathrm{NO}_{3}\right)_{2}$ solution followed by calcination at $550^{\circ} \mathrm{C}$ for $4 \mathrm{~h}$ in static air. This sample was labeled IE-0.36, with the suffix indicating the $\mathrm{Cu} / \mathrm{Al}$ ratio.

\section{Catalyst characterization}

The XRD patterns were recorded on a Rigaku Miniflex X-ray diffractometer at RT with a $\mathrm{CuK}_{\alpha}$ monochromatic radiation $(\lambda=1.5418 \AA$ ). The elemental composition of the Cu/SSZ-13 samples was determined from ICP-OES analysis (SPECTRO CIROS CCD ICP-OES with axial plasma viewing). TPR experiments were performed with a flow apparatus equipped with a fixed-bed reactor, a computercontrolled oven, and a thermal conductivity detector. Typically, an amount of the catalyst was contained between two quartz wool plugs in a quartz reactor. Before TPR, the catalyst was oxidized by exposure to a flowing mixture of $\mathrm{O}_{2}(4 \mathrm{vol} \%)$ in $\mathrm{He}$ at $300^{\circ} \mathrm{C}$ (heating rate: $\left.10^{\circ} \mathrm{C} \mathrm{min}^{-1}\right)$. After the sample was cooled to $\mathrm{RT}$ in flowing $\mathrm{N}_{2}$, the sample was reduced in $\mathrm{H}_{2}(4 \mathrm{vol} \%)$ in $\mathrm{N}_{2}$ at a flow rate of $8 \mathrm{~mL} \mathrm{~min}^{-1}$ while heating from RT to $800^{\circ} \mathrm{C}$ at a ramp rate of $10^{\circ} \mathrm{Cmin}^{-1}$.

The FTIR spectra of $\mathrm{CO}$ adsorbed to the zeolite samples were recorded in the range of $4000-400 \mathrm{~cm}^{-1}$ with a Bruker Vertex V70v instrument. The spectra were acquired at a $2 \mathrm{~cm}^{-1}$ resolution and averaged over 20 scans. The samples were prepared as thin selfsupporting wafers of $5-10 \mathrm{mg} \mathrm{cm}^{-2}$ and placed inside a controlled environment IR transmission cell, which could heat and cool, gas dose, and evacuate. Before $\mathrm{CO}$ adsorption, the catalyst wafer was heated to $550^{\circ} \mathrm{C}$ at a rate of $2^{\circ} \mathrm{Cmin}^{-1}$. Subsequently, the cell was outgassed at the final temperature until the residual pressure was below $5 \mathrm{mPa}$. CO was introduced into the sample cell via a sample loop connected to a Valco six-port valve.

The EPR spectra were recorded on a Bruker EPR A200 spectrometer. The samples $(10 \mathrm{mg})$ were introduced into the homemade quartz cup inside the microwave cavity. The EPR spectrometer settings were as follows: center field $3350 \mathrm{G}$; sweep width $200 \mathrm{G}$; microwave frequency $9.41 \mathrm{GHz}$; modulation frequency $100 \mathrm{kHz}$; power $10.00 \mathrm{~mW}$.

The Raman spectra were obtained on a homemade Raman spectrometer with a triple-stage spectrograph at a resolution of $2 \mathrm{~cm}^{-1}$. The excitation laser line at $532 \mathrm{~nm}$ from a semiconductor laser was used as an excitation source. The power of the laser on the sample was approximately $3 \mathrm{~mW}$. The scattered photons were collected in the back-scattering mode. The sample was pressed into self-supporting wafers and placed in an in situ quartz cell, equipped with gas inlet/outlet ports and a heater. Then, the samples were pretreated at $450^{\circ} \mathrm{C}$ in flowing $\mathrm{O}_{2}$ for $4 \mathrm{~h}$. The Raman spectrum was recorded after the cell was cooled to RT.

\section{DFT calculations}

All the DFT calculations were performed by using Gaussian 09 with the B3LYP hybrid exchange-correlation functional. ${ }^{[33-36]}$ The 6-311G(d) basis set was used for all atoms. The initial cluster was cut from the crystal structure. All dangling boundary bonds were saturated by $\mathrm{H}$ atoms for which the direction was constrained according to the next silicon position. At the first step, all other atoms were fixed while only $\mathrm{H}$ bond lengths were optimized. Then, the other atoms were optimized while the $\mathrm{H}$ atoms were fixed. All the frequencies obtained by using DFT calculations were compared directly with the experimental data without further correction. 


\section{Catalytic activity measurements}

The $\mathrm{NH}_{3}$-SCR reaction was performed in a parallel 10-flow microreactor system with gas mixtures containing $\mathrm{NO}(0.1 \mathrm{vol} \%), \mathrm{NH}_{3}$ (0.1 vol\%), and $\mathrm{O}_{2}(5 \mathrm{vol} \%)$ with a balance of $\mathrm{He}$. An amount of the catalyst $(10 \mathrm{mg})$ was diluted with $\mathrm{SiC}(300 \mathrm{mg})$ and contained between two quartz wool plugs in a quartz reactor with an internal diameter of $4 \mathrm{~mm}$. The total flow rate per channel was $50 \mathrm{~mL} \mathrm{~min}^{-1}$. The temperature was varied from 150 to $500^{\circ} \mathrm{C}$. The reaction rate was measured during heating of the catalyst beds at a rate of $5^{\circ} \mathrm{C} \mathrm{min}^{-1}$. Pretreatment involved heating the catalyst samples to $450^{\circ} \mathrm{C}$ overnight at a rate of $1{ }^{\circ} \mathrm{C} \mathrm{min}^{-1}$ under a He flow at a flow rate of $50 \mathrm{~mL} \mathrm{~min}^{-1}$. For analysis, the effluent gas was analyzed with a Balzers QMS-200 Omnistar mass spectrometer.

\section{Acknowledgements}

This work was financially supported by the Programme Strategic Scientific Alliances and the Joint Scientific Thematic Research Programme between China and the Netherlands.

Keywords: copper $\cdot$ Raman spectroscopy $\cdot$ SCR reaction $\cdot$ SSZ$13 \cdot$ zeolites

[1] A. Fritz, V. Pitchon, Appl. Catal. B-Environ. 1997, 13, 1-25.

[2] G. Busca, L. Lietti, G. Ramis, F. Berti, Appl. Catal. B-Environ. 1998, 18, 1 36.

[3] S. Brandenberger, O. Kroecher, A. Tissler, R. Althoff, Catal. Rev. . 2008, 50, $492-531$.

[4] S. Kieger, G. Delahay, B. Coq, B. Neveu, J. Catal. 1999, 183, 267-280.

[5] H. Yahiro, M. Iwamoto, Appl. Catal. A-Gen. 2001, 222, 163-181.

[6] M. Moliner, C. Franch, E. Palomares, M. Grill, A. Corma, Chem. Commun. 2012, 48, 8264-8266.

[7] N. Wilken, K. Wijayanti, K. Kamasamudram, N. W. Currier, R. Vedaiyan, A. Yezerets, L. Olsson, Appl. Catal. B-Environ. 2012, 111, 58-66.

[8] J. Xue, X. Wang, G. Qi, J. Wang, M. Shen, W. Li, J. Catal. 2013, 297, $56-$ 64.

[9] M. Iwamoto, H. Furukawa, Y. Mine, F. Uemura, S. I. Mikuriya, S. Kagawa, J. Chem. Soc. Chem. Commun. 1986, $1272-1273$.

[10] M. Iwamoto, H. Yahiro, Y. Torikai, T. Yoshioka, N. Mizuno, Chem. Lett. 1990, 1967-1970.

[11] H. Sjövall, L. Olsson, E. Fridell, R. J. Blint, Appl. Catal. B-Environ. 2006, 64, $180-188$.

[12] J. H. Kwak, R. G. Tonkyn, D. H. Kim, J. Szanyi, C. H. F. Peden, J. Catal. 2010, 275, 187-190.
[13] J. H. Kwak, D. Tran, S. D. Burton, J. Szanyi, J. H. Lee, C. H. F. Peden, J. Catal. 2012, 287, 203-209.

[14] J. H. Kwak, D. Tran, J. Szanyi, C. H. F. Peden, J. H. Lee, Catal. Lett. 2012, $142,295-301$.

[15] J. Hun Kwak, H. Zhu, J. H. Lee, C. H. F. Peden, J. Szanyi, Chem. Commun. 2012, 48, 4758-4760.

[16] J. Szanyi, J. H. Kwak, H. Y. Zhu, C. H. F. Peden, Phys. Chem. Chem. Phys. 2013, 15, 2368-2380.

[17] F. Gao, E. D. Walter, E. M. Karp, J. Y. Luo, R. G. Tonkyn, J. H. Kwak, J. Szanyi, C. H. F. Peden, J. Catal. 2013, 300, 20-29.

[18] J. S. Woertink, P. J. Smeets, M. H. Groothaert, M. A. Vance, B. F. Sels, R. A. Schoonheydt, E. I. Solomon, Proc. Natl. Acad. Sci. USA 2009, 106, 18908 18913.

[19] L. Wang, W. Li, G. Qi, D. Weng, J. Catal. 2012, 289, 21 -29.

[20] U. Deka, A. Juhin, E. A. Eilertsen, H. Emerich, M. A. Green, S. T. Korhonen, B. M. Weckhuysen, A. M. Beale, J. Phys. Chem. C 2012, 116, 4809-4818.

[21] U. Deka, I. Lezcano-Gonzalez, S. J. Warrender, A. L. Picone, P. A. Wright, B. M. Weckhuysen, A. M. Beale, Microporous Mesoporous Mater. 2013, $166,144-152$.

[22] U. Deka, I. Lezcano-Gonzalez, B. M. Weckhuysen, A. M. Beale, ACS Catal. 2013, 3, 413-427.

[23] D. W. Fickel, J. M. Fedeyko, R. F. Lobo, J. Phys. Chem. C 2010, 114, 1633 1640.

[24] L. Ren, L. Zhu, C. Yang, Y. Chen, Q. Sun, H. Zhang, C. Li, F. Nawaz, X. Meng, F.-S. Xiao, Chem. Commun. 2011, 47, 9789-9791.

[25] L. Ren, Y. Zhang, S. Zeng, L. Zhu, Q. Sun, H. Zhang, C. Yang, X. Meng, X. Yang, F.-S. Xiao, Chin. J. Catal. 2012, 33, 92-105.

[26] R. Martinez-Franco, M. Moliner, J. R. Thogersen, A. Corma, ChemCatChem 2013, DOI: 10.1002/cctc.201300141.

[27] M. Moliner, C. Martinez, A. Corma, Chem. Mater. 2013, DOI: 10.1021/ cm4015095.

[28] R. Martínez-Franco, M. Moliner, C. Franch, A. Kustov, A. Corma, Appl. Catal. B-Environ. 2012, 127, 273-280.

[29] S. C. Larsen, A. Aylor, A. T. Bell, J. A. Reimer, J. Phys. Chem. 1994, 98, $11533-11540$.

[30] P. Vanelderen, J. Vancauwenbergh, B. F. Sels, R. A. Schoonheydt, Coord. Chem. Rev. 2013, 257, $483-494$.

[31] F. Giordanino, P. N. R. Vennestrom, L. F. Lundegaard, F. N. Stappen, S. Mossin, P. Beato, S. Bordiga, C. Lamberti, Dalton Trans. 2013, 42, 12741 12761.

[32] M. J. Henson, P. Mukherjee, D. E. Root, T. D. P. Stack, E. I. Solomon, J. Am. Chem. Soc. 1999, 121, 10332-10345.

[33] Gaussian 09, revision A.02, M. J. Frisch, G. W. Trucks, H. B. Schlegel, et al. Gaussian Inc., Wallingford CT, 2009.

[34] A. D. Becke, J. Chem. Phys. 1993, 98, 5648-5652.

[35] A. D. Becke, Phys. Rev. A 1988, 38, 3098-3100.

[36] C. Lee, W. Yang, R. G. Parr, Phys. Rev. B 1988, 37, 785- 789.

Received: September 14, 2013

Published online on December 11, 2013 